\title{
Acceptance of Change Behaviour among Middle Managers: The Importance of Subjective Norms and Social Influence as Environmental Predictors
}

\author{
Safuwan Samah ${ }^{1}$ \\ Policy and Negotiation Unit, Public Service Department of Malaysia \\ Correspondence: Safuwan Samah. Tel: 603-8885-5316. E-mail: safuwan.samah.gov@gmail.com
}

Received: January 5, 2018

doi:10.5539/ass.v14n2p155

\author{
Accepted: January 11, $2018 \quad$ Online Published: January 29, 2018 \\ URL: https://doi.org/10.5539/ass.v14n2p155
}

\begin{abstract}
The study seeks to examine the influence of environmental-related factors among middle managers in Malaysian government organization. Specifically, this study seeks to determine the influence of subjective norms and social influence in public organizations on acceptance of change. Present study employed cross-sectional survey involving a sample of 400 Administrative and Diplomatic Officers (ADO) in Malaysian Public Service organizations. The findings highlighted that middle managers' subjective norms in this study were significant in influencing acceptance of change but are not affected by their social pressure when changes are implemented. Practically, this investigation proffers essential effort in understanding the acceptance of change of middle managers in public service organizations. This study suggests ADO as change agents should be well informed and consulted to create social pressure among them to act in supportive ways of implementing planned change Theoretically, the results of this study append to the literature and to a certain extent provide better explanation of Theory of Reasoned Action and Social Cognitive Theory in the context of acceptance of change. The population of this study involved ADO as middle managers in Malaysian Public Service organizations thus the results cannot be generalized to other level of employees in public sector as well as private service organizations. A comparative study involving both public and private service organizations would be worth studying in future.
\end{abstract}

Keywords: organizational change, environmental-related factors, subjective norms, social influence, acceptance of change

\section{Introduction}

In recent decades, organizations are constantly implementing changes to improve their work processes and outcomes to keep up with the changing demands (Augustsson, Richter, Hasson \& Scharz, 2017; Safuwan, 2016). However, the change process is exclusive for each organization due to the differences in the nature of the organization, the nature of the business, the work culture and values, management and leadership style, and also the behaviour and attitude of the employees (Abdul Rashid, Sambasivan \& Abdul Rahman, 2004). Consequently, changes can occur as a result of new thinking, advances in technology, innovation and progress, knowledge and communication, as well as mergers, takeovers, layoffs, and downsizing (Abdullah, Mansor, \& Hamzah, 2013).

Successful organizational change can be challenging to accomplish, however, with employees' readiness for change, and accept the change; the change effort will be more effective. Studies proved that employees' acceptance and support of change is critical to achieve the desired organizational change (Augustsson, Richter, Hasson \& Schwarz, 2017; Nielsen \& Randall, 2012, Miller, Johnson \& Grau, 1994; Armenakis, Harris \& Mossholder, 1993). Past research also demonstrated that employee reactions, attitudes and beliefs about change have substantial impacts on the progress and outcome of the organization (Nielsen \& Randall, 2012).

\section{The context of organizational change in Malaysia}

In the world of uncertainty, Malaysia Public Service (MPS) faces a lot of new challenges especially in the form of demands and expectations from customers and stakeholders. The rapid development occurred local and abroad has pressured MPS beyond international borders in which it requires higher expertise than the existing. Therefore, changes in many aspects are necessary so that it can improve the effectiveness and the efficiency of services to meet the needs of stakeholders.

In this regard, Malaysia's government has introduced National Transformation Policy (NTP) which aimed at 
transforming towards achievement of a developed country with high income nation by the year 2020 . The Government has also introduced several initiatives under NTP such as the Government Transformation Program (GTP), the Economic Transformation Program (ETP), the Political Transformation Program (PTP) and the Social Transformation Program (STP) with five (5) strategic thrusts which are: 1) revitalizing public servants that focuses on increasing the competency, performance, productivity and innovation skills of public servants; 2 ) reengineering public organizations to increase capability and revitalize public organizations; 3) enhancing service delivery to increase the efficiency and effectiveness of service delivery; 4) inclusiveness and ownership that focuses in improving networking and strategic collaboration for local and international; and 5) enculturing shared values to cultivate the spirit of patriotism, shared values, ethos and integrity (Public Service Department of Malaysia). As MPS plays important role as change agent in government, these governmental wishes through implementation of these programs will not be achieved if public service fails to implement changes in line with current needs and requirements.

However, the biggest concern to transform the public service, currently, is how to shape an institutional culture among civil servants to accept and supports the new service delivery model to serve and to give the best for the citizen. Through numerous planned organizational change initiatives that have been implemented by the government, thus, civil servants' issue on acceptance of change (AOC) is a main restraining force behind the limited results of some of the initiatives (Malaysia Prime Minister Office, 2015).

\section{Research Problem}

Although past studies showed that change initiatives are somewhat the norm for companies, but different industry sectors each display their own characteristics (Bellou \& Chatzinikou, 2015). Whilst organizational change phenomenon emerges with the increasing frequency and magnitude in any sectors, most of the major studies of organization change focus on the private sectors (Coram \& Burnes, 2001) and mostly involved private sector managers (Safuwan, 2017). Empirical evidence showed that there is less research conducted on organizational change and the employee reaction in public organization (Van der Voet, Kuipers, \& Groeneveld, 2016) especially among the Management and Professional Group officers as middle managerial level as sample (Battilana, Gilmartin, Sengul, Pache, \& Alexander, 2010). In view of this situation, there is research gap to determine the issue of acceptance of change in public organization.

\section{Theoretical Perspective}

\subsection{Conceptualization of Acceptance of Change Behaviour}

Acceptance of change behaviour consists of positive and negative behaviour. Past research referred positive acceptance of change behaviour as intended actions that depart from the norms of the organizations, but it is done in an honorable way (Spritzer \& Sonenshein, 2004). Research by Bovey and Hede (2001) discoverd that employee acceptance of change is consists of four dimensions: 1) openly expressive support; 2) concealed support; 3) active support; and 4) passive support. Thus, it shows that when employees are openly expressive and active, they will be likely more initiate and embrace the actions. On the contrary, if the employees are openly expressive but passive, the will recognize and accept the proposed changes. Accordingly, concealed and active support means employees will give full cooperation, but concealed and passive support means they are adhere to the changes made (Johannsdottir, Olafsson, \& Davidsdottir, 2015).

Meanwhile, recent study by Fabio and Gori (2016) expressed that acceptance is regarded as positive behaviour for an individual and the acceptance of change is the individual's tendency to embrace rather than to abstain from the changes occur in the workplace. The study also emphasized that AOC may come from the person's belief that people who are able to accept the change will see changes as something that will benefit in their working lives.

In contrast, negative acceptance of change behaviours involves resistance to change, act negatively (overtly or covertly) towards the changes, spreading negative rumours (Oreg, Vakola, \& Armenakis, 2011), and other types of negative behaviours that bear negative implications to the organization and its associates. However, this study's focus is on the constructive behaviour of acceptance of change due to its vital impacts on organizations and their stakeholders, such as customers, employees, and employers (Spector \& Fox, 2005).

\subsection{Theory of Reasoned Action and Social Cognitive Theory}

The literature pointed to two major theoretical frameworks of employees' acceptance of change. The first theory is the Theory of Reasoned Action (TRA) by Ajzen \& Fishbein (1980). In order to explain human behaviour, Ajzen and Fishbein developed a model from TRA to predict human behaviour by defining the links between individual's attitude, subjective norms, behavioural intentions and the behaviour. The theory also illustrated that 
individual behaviour is directly influenced by their behavioural intention, which in turn, their behavioural intention is determined by two parts of determinants namely attitudes towards the act or behaviour and subjective norms, thus proving the best predictor or indicator of a given behaviour.

Ajzen and Fishbein (1980) referred attitude as the individual's willingness that will impact the development of a particular behaviour, the belief towards behaviour and the evaluation made to these beliefs. With regards to the latter variable, the subjective norm reflects the impact on the individual of the opinion of others such as family or friends ultimately influencing the individual's behaviour.

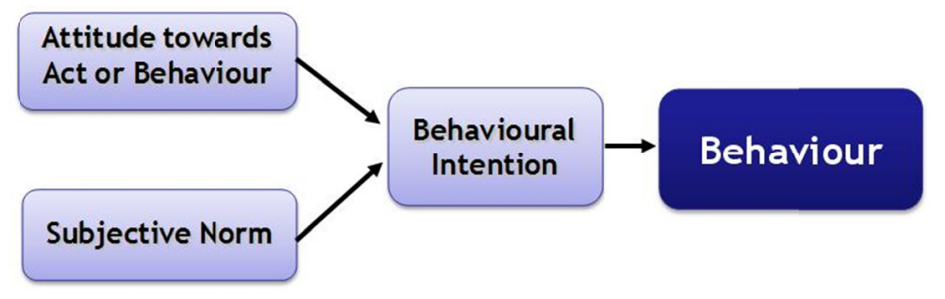

Figure 1. Model of Theory of Reasoned Action (1975)

Source: Ajzen \& Fishbein (1980)

Figure 1 show the model formed from the Theory of Reasoned Action by Ajzen \& Fishbein (1980). There two parts of determinants that lead to individual's intention and behaviour. The first determinant is individual attitude towards behaviour that refers to individual's belief and evaluation or appraisal about the outcomes or behaviour. Consequently, these will reflect to the individual's cognitive belief signify that attitude towards behaviour is their own perception towards the behaviour act (Moss, 2008). The second determinant is subjective norm as refer to Ajzen (1991) is social pressure that individual deem as significant person people to them. This meaning reflects that individual belief and concern about other people attitude towards behaviour and ultimately will motivate them to fulfil others' attitude. For instance, the opinion of family and friend may influence the individual intention and decision whether to perform a particular behaviour or not.

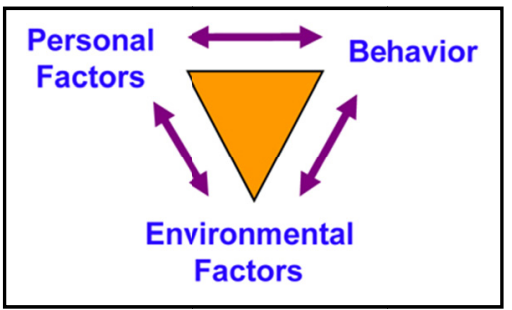

Figure 2. Triadic Reciprocal Determinism

Source: Bandura (1986)

The second theory is Social Cognitive Theory (SCT). This theory was pioneered by Albert Bandura (1986b) to anticipate human behaviour. The theory emphasized that the cognitive (personal factors) and environment (environmental factors) influence behaviour and behaviour also influence the cognitive and environment. This concept known as triadic reciprocal determinism (Figure 2) where individual cognitive, the world and the behaviour of persons are mutually caused. Bandura believes that human conduct must be explained in terms of the three factors of reciprocal interaction: cognitive, behavioural, and environmental determinants.

The unique feature of SCT is the emphasis on social influence and its emphasis on external and internal social reinforcement. SCT considers the unique way in which individuals acquire and maintain behaviour, while also considering the social environment in which individuals perform the behaviour (Cole, Schaninger, \& Harris, 2002). Accordingly, this research proposed that the employee's individual attributes i.e. feelings towards change and confidence in dealing with change, and organizational environmental i.e. interaction with their supervisors, officemate (colleagues), and peers as well as social connection can reinforce the acceptance behaviour in the implementation of change in organization. These two importance factors will stimulate the cognitive and social factors of the employees and can help them to decide if the observed behaviours should be imitated or not. As Bandura taken into consideration the effect of environment along with the effect of individual's cognitive by 
recognizing the thinking processes that individuals experience in determining how to behave in the workplace, this theory is adequate to explain the factors associated with behaviour and is adaptable for circumstances of dynamic process relating events and features of particular behaviour at the workplace of employee (Steers et al., 2004).

In Malaysia Public Service, since ADO (Management and Professional Group) have committed to work for the interest of the government and serve the nation, they have the ability and responsibility to engage in the PST. Therefore, the researcher believed that the SCT and TRA were complementary and appropriate theories to explain the variables of this research.

\subsection{Environmental Factors and Acceptance of Change}

This study focused on the environmental factors towards acceptance of change. Significantly, many previous researches on AOC pointed out that certain environmental-related variables do influence individual AOC in workplace setting (see Wikhamn \& Hall, 2012; Ferris et al., 2009; Henle, 2005; Faridahwati, 2003; Fox, Spector \& Miles, 2001; Bennett \& Robinson, 2000; Armenakis \& Bedeian, 1999; Baldridge \& Burnham, 1975). In this study, researcher looked into two environmental-related factors which were subjective norms and social influence.

As such, several studies have discussed the impact of subjective norms on person AOC specifically on their personal proficiencies, social capabilities, ethical conduct, and acceptance of technology (Shoss, Eisenberger, Restubog, \& Zagenczyk, 2013; Emmerling \& Goleman, 2003; Sivanathan \& Fekken, 2002; Svyantek \& Abdul Rahim, 2002; Goleman, Boyatzis, \& McKee, 2001). Moreover, studies by MdNor and Zainal (2009) and MdNor, AbuShanab and Pearson (2008) found that subjective norms do have significant impact on individual acceptance towards the advancement of technology. Other researchers have also provided evidence that subjective norms contributed to various forms of workplace positive behaviour (Sady, Spitzmuller, \& Witt, 2008; Eder \& Eisenberger, 2006). Similarly, recent studies such as Salami (2010) on 422 secondary school teachers from Southwest Nigeria and Omar et al. (2011) on 165 civil staffs also had identified that subjective norms is positively correlated and one of the prominent factors in explaining employees' behaviour on AOC.

On the other hand, social influence can also contribute to explain a variety of human behaviour, cognitive, motivational processes, and emotions (Kelly, 2001). Specifically, a person's, officemate (colleagues), peers, superior, spouse and etc. were known to be the significant change agent to individual decision in the concept of change management (Wainwright, 2008; Caldwell, 2003). A clear finding in Oreg (2006) study also found that social influence is indeed an antecedent to acceptance to change as he concluded that an individual who is surrounded by those who accept the change, it is at least as likely to follow their social affiliations and accept the change as well. As such, a person's sense or need to belong in group will motivate individual to behave according to group behaviour even though there is no influence by them.

Based on the above discussion, this study hypothesises:

H1: Subjective norms significantly influences acceptance of change among Management and Professional Group of ADO in Malaysia Public Service organization.

H2: Social influence significantly influences acceptance of change among Management and Professional Group of ADO in Malaysia Public Service organization.

\section{Methodology}

\section{Population and Sampling}

A total of 400 ADO from Grade 41 to Grade 54 that currently serving in MPS organizations were chosen as the sample for this study. The total population of ADO serve with government is 6,904 under 25 ministries. A pilot study was performed with 30 samples prior to the actual study to measure the internal consistency of all research variables. Based on the analysis, acceptance of change, social norms and social influence inventory were found to be good and highly reliable with Cronbach alpha of $0.84,0.75$ and 0.92 respectively. On the actual data collection, a cross-sectional survey was employed, and the completed questionnaires were distributed with the assistance from Human Resource Management Division (HRMD). From a total of 420 questionnaires that were distributed, 400 questionnaires were returned; resulting in $95.2 \%$ usable response rate.

\section{Research Instruments}

The present study was based on structured survey questionnaire consisted of four sections. Section A of the survey questionnaire required demographic information of respondents (e.g. gender, age group, marital status, level of education, grade of position and years of tenure in service). Section B was based on Organizational 
Change Questionnaire (OCQ) by Bouckenooghe, D., Devos, G., and van den Broeck, H. (2009) to measure respondents' acceptance of change. Section $\mathrm{C}$ was based on instruments developed by Vakola, Tsaousis and Nikolaou (2003); Antoni (2004) and Walker et al. (2007) in Mansor et. al. (2013) and Section D was based on Social Influence Scale (SIS) by Kidwell, Mossholder, \& Bennet (1997) to measure respondents' subjective norms and social influence respectively. Based on review of literature, instruments used are most suitable tool in measuring research variables and its validity have been confirmed for many related research and the reliability achieved the satisfactory level of coefficient alpha .7. As these instruments have been employed by many researches on acceptance of change in many contexts, the adaptability advantage is undeniable.

\section{Data Analysis}

To be able to answer statement of problem and objectives of study, present study used inferential statistical techniques i.e. Pearson Correlation analysis and Simple Linear Regression. The Pearson analysis was used to determine the correlation between environmental factors i.e. subjective norms and social influence. Supplementary, in order to investigate the research hypotheses, regression analysis was conducted.

\section{Respondents'profile}

Descriptive analysis was conducted to obtain respondents' profiles based on gender, age group, marital status, level of education, grade of position and years of tenure in service.

Table 1. Demographic Profiles of the Respondents $(n=400)$

\begin{tabular}{|c|c|c|}
\hline Profile & Frequency & Percentage \\
\hline \multicolumn{3}{|l|}{ Gender } \\
\hline Male & 158 & 39.50 \\
\hline Female & 242 & 60.50 \\
\hline \multicolumn{3}{|l|}{ Age (years) } \\
\hline $20-30$ & 59 & 14.75 \\
\hline $31-40$ & 257 & 64.25 \\
\hline $41-50$ & 73 & 18.25 \\
\hline 51 and above & 11 & 2.75 \\
\hline \multicolumn{3}{|l|}{ Marital Status } \\
\hline Single & 105 & 26.25 \\
\hline Married & 295 & 73.75 \\
\hline \multicolumn{3}{|l|}{ Education Level } \\
\hline Degree & 257 & 64.25 \\
\hline Master & 139 & 34.75 \\
\hline $\mathrm{PhD}$ & 4 & 1.00 \\
\hline \multicolumn{3}{|l|}{ Grade Level } \\
\hline $41-44$ & 203 & 50.75 \\
\hline 48 & 104 & 26.00 \\
\hline 52 & 55 & 13.75 \\
\hline 54 & 38 & 9.50 \\
\hline \multicolumn{3}{|l|}{ Tenure (years) } \\
\hline $1-5$ & 81 & 20.25 \\
\hline $6-10$ & 169 & 42.25 \\
\hline $11-15$ & 108 & 27.00 \\
\hline 16 and above & 42 & 10.50 \\
\hline
\end{tabular}

Table 1.0 shows that the sample consisted $39.5 \%$ males and $60.5 \%$ females; with the majority of $64.25 \%$ respondents were between 31 and 40 years old, $18.25 \%$ were between 41 and 50 years old, $14.75 \%$ were between 20 and 30 years old, and $2.75 \%$ were 51 years old and above. Among 400 respondents, $26.25 \%$ were single and 73.75 were married. Table 1.0 also provides the highest education level of respondents. From 400 respondents, $64.25 \%$ have a bachelor degree, $34.75 \%$ have master degree and only $4.0 \%$ have $\mathrm{PhD}$. Descriptive analysis also provides a breakdown of grade level of respondents. Of $400 \mathrm{ADOs}$, the highest number of participants were from the grades M41 to M44 (50.75\%) followed by $26.00 \%, 13.75 \%$ and $9.50 \%$ were from the grades M48, M52 and M54 respectively. 


\section{Results}

The bivariate relationships among the research variables of present study i.e. acceptance of change $(\mathrm{M}=2.19$, $\mathrm{SD}=.41)$, subjective norms $(\mathrm{M}=2.59, \mathrm{SD}=.50)$, and social influence $(\mathrm{M}=2.74, \mathrm{SD}=.47)$ were examined using the Pearson's correlation analysis. The summary of the results is given in Table 2.0.

Table 2. Pearson Product-Moment Correlations between Subjective Norms, Social Influence and Acceptance of Change $(\mathrm{n}=400)$

\begin{tabular}{lll}
\hline Measures & 1 & 2 \\
\hline 1) Acceptance of Change & $.324^{* *}$ & \\
2) Subjective Norms & $.174^{* *}$ & .372 \\
3) Social Influence &
\end{tabular}

**Comparisons is significant at the 0.01 level (2-tailed)

Table 2.0 shows that both independent variables are positively correlated with the acceptance of change with subjective norms with $\mathrm{r}(400)=.324, \mathrm{p}=.01$; acceptance of change with social influence $\mathrm{r}(400)=.174, \mathrm{p}=.01$; and subjective norms with social influence $\mathrm{r}(400)=.372, \mathrm{p}=.01$. Based on Rule of Thumbs, these results indicate that acceptance of change and subjective norms is moderately correlated. Similarly, subjective norms and social influence was found to have moderate association. In addition, Pearson Correlation analysis found that the association between acceptance of change and social influence is significantly weak correlated.

As further analysis was conducted, multiple regression analyses were conducted to determine the influence of environmental-related variables and acceptance of change on Administrative and Diplomatic Officers (ADO) in Malaysian Public Service organizations. The results are shown in Table 3.0.

Table 3. Estimates of Coefficients for the Model

\begin{tabular}{cccccc}
\hline & $\begin{array}{c}\text { B (Unstandardized } \\
\text { Coefficients) }\end{array}$ & $\begin{array}{c}\text { Std. } \\
\text { Error }\end{array}$ & $\begin{array}{c}\text { Beta (Standardized } \\
\text { Coefficients) }\end{array}$ & $\mathrm{t}$ & $p$-value \\
\hline Constant & 1.987 & .253 & & 7.866 & .000 \\
Subjective Norms $\left(\mathrm{X}_{1}\right)$ & .401 & .068 & .300 & 5.882 & .000 \\
Social Influence $\left(\mathrm{X}_{2}\right)$ & .059 & .048 & .062 & 1.218 & .224 \\
\hline
\end{tabular}

*Notes: $\mathrm{R}=.329 ; \mathrm{R}^{2}=.108 ;$ Adj. $\mathrm{R}^{2}=.104 ; \mathrm{F}=24.037 ;{ }^{*} \mathrm{p}=.000$

The results from Table 3.0 reveal that $10.8 \%$ of the variances in acceptance of change $\left(\mathrm{R}^{2}=.108\right)$ are explained by the independent variables. The explanation is significant $(F=24.037 ; p=.000)$. Results further shows that subjective norms is significant $(\mathrm{p}<.05)$ in contributing to the explanation to the variances in acceptance of change $(t=5.882)$. However, there is no significant linear positive relationship $(p>.05)$ between acceptance of change behaviour and social influence $(\mathrm{t}=1.218)$. The research finding supports the hypothesis that subjective norms variable contributed to various behaviour of accepting change and the best environmental-related factor that can explain the acceptance of change behaviour among the ADO in the Malaysian Public Services organizations.

\section{Discussion}

This study highlights on the aspect of acceptance of change behaviour among the ADO in the Malaysian Public Services organizations. The regression analysis discovered that the employees' subjective norms in this study were significant in influencing acceptance of change. The Management and Professional Group, particularly the ADOs are more likely to have perceived social obligation either to act or not to act towards organizational change. This finding is essential so when the middle managers believe that the other people (i.e. family or friends) opinion is positive towards the changes proposed thus gives impact to their behaviour, and they derived acceptance and oblige positively to changes. Another likely reason for this correlation is that in the workplace context, individuals are likely to be motivated to comply with views from others who are important to them (Ham, Jeger \& Ivković, 2015). In addition, this finding is consistent with past researches such as Salami (2010) and Omer et al. (2011) that proved managers regardless their level in public service organizations tend to play 
their role significantly by adapting to changes when they experienced a positive subjective norms environment from their supervisors, colleagues, peers as well as family members.

For the social influence factor, we intended to investigate whether middle managers experience a deep sense of need to feel in a group with their social environment and feel that it is a requirement for their social collaborations. This study is interested in knowing whether the middle managers are able to accept organizational changes with the pressure from social components. The result of this study shows that the middle managers in public service organizations are not affected by their social pressure when changes are implemented. Contrary to the expectation, this finding is contradicted with previous studies such as Caldwell (2003), Wainwright (2008) and Oreg (2006). This study involved more than half of the respondents consisted of those who are Generation Y. Known as generation of multi-taskers, Generations Y are always expecting to be given opportunities to learn new things and to bring tremendous values to organization. Differ from their predecessors, this generation is characterized as those who understand the need to adopt new strategies (Bakowska, 2013), desire to work at organization with more flexible structure and practices (Tolbize, 2008), always optimistic (Kersten, 2002), embrace diversity (The National Oceanographic and Atmospheric Office of Diversity, 2005) and adaptable to changes (Jenkins, 2007). Thus, the researcher acknowledged that the distinct result may be caused by the different composition of the sample in this study.

\section{Conclusion}

Overall, the middle managers in public service organizations perceived subjective norms in their acceptance of change but not social influence. Practically, this investigation proffers essential effort in understanding the acceptance of change of middle managers in public service organizations. This study suggests ADO as change agents should be well informed and consulted to create social pressure among them to act in supportive ways of implementing planned change Theoretically, the results of this study append to the literature and to a certain extent provide better explanation of SCT and TRA in the context of acceptance of change.

This study only focuses on two environmental-related factors namely subjective norms and social influence. Future studies could consider other factors within the frame of acceptance of change in public service organizations to gain better understanding. It should be noted that the population of this study is Administrative and Diplomatic Officers (ADO) as middle managers in Malaysian Public Service organizations thus the results cannot be generalized to other level of employees in public sector as well as private service organizations. A comparative study involving both public and private service organizations would be worth studying in future. As this study concerns the behaviour of generation Y on acceptance of change in workplace context, it is essential for future studies to consider employing a comparative study on different generations within the same framework.

\section{Acknowledgement}

The author would like to express his gratitude to Prof. Dr. Bahaman Abu Samah, Assoc. Prof. Dr. Khairuddin Idris and Prof. Dr. Turiman Suandi, Senior Lecturers, Professional Development and Continuing Education Department, Universiti Putra Malaysia.

\section{References}

Abdul Rashid, Z., Sambasivan, M., \& Abdul Rahman, A. (2004). The influence of organizational culture on attitudes toward organisational change. Leadership \& organisation development Journal, 25(2), 161-179.

Abdullah, N. R. W., Mansor, N. B., \& Hamzah, A. (2013). Keeping ahead of the game: Innovations and challenges in e-government in Malaysia. The Economic and Labour Relations Review, 24(4), 549-567. https://doi.org/10.1177/1035304613508868

Ajzen, I. (1991). The theory of planned behaviour. Organisational behaviour and human decision processes, $50(2), 179-211$.

Ajzen, I., \& Fishbein, M. (1980). Understanding attitudes and predicting social behaviour.

Antoni, C. (2004). Research Note: A Motivational Perspective on Change Processes and Outcomes. European Journal of Work and Organizational Psychology, 13(2), 197-216.

Armenakis, A. A., \& Bedeian, A. G. (1999). Organisational change: A review of theory and research in the 1990s. Journal of management, 25(3), 293-315.

Armenakis, A. A., Harris, S. G., \& Mossholder, K. W. (1993). Creating readiness for organisational change. Human relations, 46(6), 681-703. 
Augustsson, H., Richter, A., Hasson, H., \& von Thiele Schwarz, U. (2017). The Need for Dual Openness to Change: A Longitudinal Study Evaluating the Impact of Employees' Openness to Organisational Change Content and Process on Intervention Outcomes. The Journal of Applied Behavioural Science, 0021886317691930.

Bąkowska, J. (2013). Managing Generation Y Employees in an International Company. MBA Poznań-Atlanta.

Baldridge, J. V., \& Burnham, R. A. (1975). Organisational innovation: Individual, organisational, and environmental impacts. Administrative science quarterly, 165-176.

Bandura, A. (1986b). Social foundations of thought and action: A social cognitive theory. Englewood Cliffs, NJ: Prentice-Hall.

Battilana, J., Gilmartin, M., Sengul, M., Pache, A. C., \& Alexander, J. A. (2010). Leadership competencies for implementing planned organisational change. Leadership Quarterly, 21(3), 422-438. https://doi.org/10.1016/j.leaqua.2010.03.007

Bellou, V., \& Chatzinikou, I. (2015). Preventing employee burnout during episodic organisational changes. Journal of Organisational Change Management, 28(5), 673-688.

Bennett, R. J., \& Robinson, S. L. (2000). Development of a measure of workplace deviance. Journal of Applied Psychology, 85(3), 349-360.

Bouckenooghe, D., Devos, G., \& van den Broeck, H. (2009). Organisational Change Questionnaire-Climate of Change, Processes, and Readiness: development of a new instrument. The Journal of Psychology, 143(6), 559-599. https://doi.org/10.1080/00223980903218216

Bovey, W. H., \& Hede, A. (2001). Resistance to organisational change: the role of cognitive and affective processes. Leadership \& Organisation Development Journal, 22(8), 372-382. https://doi.org/10.1108/01437730110410099

Caldwell, R. (2003). Models of change agency: a fourfold classification. British Journal of Management, 14(2), 131-142.

Cole, M. S., Schaninger, W. S., \& Harris, S. G. (2002). The Workplace Social Exchange Network. Group \& Organisation Management, 27(1), 142-167. https://doi.org/10.1177/1059601102027001008

Coram, R., \& Burnes, B. (2001). Managing organisational change in the public sector-Lessons from the privatisation of the Property Service Agency. International Journal of Public Sector Management, 14(2), 94-110.

Eder, P. \& R. Eisenberger (2006). Perceived organisational support: overcoming work group deviance. Working paper, University of Delaware.

Emmerling, R. J., \& Goleman, D. (2003). Emotional intelligence: Issues and common misunderstandings. Issues in Emotional Intelligence, 1(1), 1-32.

Fabio, A. D., \& Gori, A. (2016). Developing a new instrument for assessing acceptance of change. Frontiers in Psychology, 7.

Faridahwati, M. F. (2003). Workplace deviance among hotel employees: An exploratory survey. Malaysian Management Journal, 7(1), 17-33.

Ferris, G. R., Liden, R. C., Munyon, T. P., Summers, J. K., Basik, K. J., \& Buckley, M. R. (2009). Relationships at work: Toward a multidimensional conceptualization of dyadic work relationships. Journal of Management, 35(6), 1379-1403.

Fox, S., Spector, P. E., \& Miles, D. (2001). Counterproductive work behavior (CWB) in response to job stressors and organizational justice: Some mediator and moderator tests for autonomy and emotions. Journal of vocational behavior, 59(3), 291-309.

Goleman, D., Boyatzis, R., \& McKee, A. (2001). Primal leadership: The hidden driver of great performance. Harvard business review, 79(11), 42-53.

Ham, M., Jeger, M., \& Ivković, A. F. (2015). The role of subjective norms in forming the intention to purchase green food. Economic Research-Ekonomska Istraživanja, 28(1), 738-748.

Henle, C. A. (2005). Predicting workplace deviance from the interaction between organizational justice and personality. Journal of Managerial Issues, 247-263. 
Jenkins, J. (2007). Leading the four generations at work. Retrieved April 15, 2008, from http://www. amanet.org/movingahead/editorial.cfm?Ed=452

Johannsdottir, L., Olafsson, S., \& Davidsdottir, B. (2015). Leadership role and employee acceptance of change. $\begin{array}{llll}\text { Journal of Organisational Change } & \text { Management, }\end{array}$ https://doi.org/10.1108/JOCM-12-2013-0238

Kelly, J. R. (2001). Mood and emotion in groups. In M. A. Hogg \& R. S. Tindale (Eds.). The Blackwell handbook of social psychology, Vol. 3: Group processes (pp. 164-181). Oxford, UK: Blackwell.

Kersten, D. (2002). Today's generations face new communication gaps. Retrieved April 15, 2008, from http://www.usatoday.com/money/jobcenter/ workplace/communications/2002

Kidwell, R. E., Mossholder, K. W., \& Bennett, N. (1997). Cohesiveness and organisational citizenship behaviour: A multilevel analysis using work groups and individuals. Journal of Management, 23(6), 775-793.

Malaysia Prime Minister Office (2015). Government Transformation Programme. Available from: http://www.pemandu.gov.my/gtp/About_GTP

Mansor, M. F, Mat, N., Abu, N. H \& Johari, A.N. (2013). Factors influencing intention resistance to change: A study of service organisation in Malaysia. Journal of Applied Sciences, 9(4), 2620-2630.

MdNor, K., \& Zainal, M. P. (2009). Internet Banking Acceptance of Malay and Chinese Ethnic Group in Malaysia. Based on The Theory of Planned Behavior.Proceedings of the 4th International Conference on Information Technology ICIT.3-5 June. Al-Zaytoonah University, Jordan.

MdNor, K., AbuShanab, E.\& Pearson, M. (2008). Internet banking acceptance in Malaysia based on the theory of Reasond Action. Journal of Information Systems and Technology Management, 5(1), 3-14.

Miller, V. D., Johnson, J. R., \& Grau, J. (1994). Antecedents to willingness to participate in a planned organisational change.

Moss, S. (2008). Theory of planned behavior. Psychlopedia, Everything Psychology. Retrieved December21, 2017 from http://www.psych-it.com.au/Psychlopedia/article.asp?id=69

Nielsen, K., \& Randall, R. (2012). The importance of employee participation and perceptions of changes in procedures in a teamworking intervention. Work \& Stress, 26(2), 91-111.

Omar, A. A., Lolli, J., Chen-McCain, S. L., \& Dickerson, J. (2011). A comparison between full and part-time lodging employees on job satisfaction, organizational commitment, and job performance.

Oreg, S. (2006). Personality, context, and resistance to organisational change. European Journal of Work and Organisational Psychology, 15(1), 73-101. https://doi.org/10.1080/13594320500451247

Oreg, S., Vakola, M., \& Armenakis, A. (2011). Change recipients' reactions to organisational change A 60 -year review of quantitative studies. The Journal of Applied Behavioural Science, 47(4), 461-524.

Public Service Department of Malaysia. (Unknown date). Transforming Public Service in Malaysia: Guidelines for Developing A Transformation Plan. Retrieve December 21, 2017 from http://docs.jpa.gov.my/docs/transformasi/Manual/Guidelines_Transformation.pdf

Sady, K., Spitzmüller, C., \& Witt, L.A. (2008). Good employee, bad business: An interactionist approach to workplace deviance. Presented at the annual meeting of the Academy of Management, Anaheim.

Safuwan, S. (2016). Reactions to Planned Organizational Change: The Review of Resistance Behaviour. In Salmah A., Azizah Z. A., Shaifol Yazam, M., Rusniah, S., Khairil Ridzuan, K., Najah, M. A., Noor Syafini, Z., Mohd Dasuki, S., Sazali, I., \& Nurhaznita, M. (Eds.). UPM-SAGE Publications Young Writer's Award 2015 Papers (pg. 191-213). Serdang, Malaysia: Perpustakaan Sultan Abdul Samad, Universiti Putra Malaysia.

Safuwan, S. (2017). The Roles of Managers and Acceptance of Change in the Public Sector. International Journal of Academic Research in Business and Social Sciences, 7(9), 1-18.

Salami, S. O. (2010). Job stress and counterproductive work behaviour: Negative affectivity as a moderator. The Social Sciences, 5(6), 486-492.

Shoss, M. K., Eisenberger, R., Restubog, S. L. D., \& Zagenczyk, T. J. (2013). Blaming the organisation for abusive supervision: The roles of perceived organisational support and supervisor's organisational embodiment. Journal of Applied Psychology, 98(1), 158-168. 
Sivanathan, N., \& Fekken, G. C. (2002). Emotional intelligence, moral reasoning and transformational leadership. Leadership \& Organisation Development Journal, 23(4), 198-204.

Spector, P. E., \& Fox, S. (2005). A stressor-emotion model of counterproductive work behaviour. Washington, DC: American Psychological Association.

Spritzer, G. M., \& Sonenshein, S. (2004). Toward the construct definition of positive deviance. American Behavioural Scientist, 47(6), 828-847.

Svyantek, D. J., \& Afzalur Rahim, M. (2002). Links between emotional intelligence and behaviour in organisations: Findings from empirical studies. The international journal of organisational analysis, 10(4), 299-301.

The National Oceanographic and Atmospheric Association Office of Diversity (2006). Tips to improve the interaction among the generations: Traditionalists, boomers, X'ers and nexters. Retrieved April 15, 2008, from http://honolulu. hawaii.edu/intranet/committees/FacDevCom/ guidebk/teachtip/intergencomm.htm

Tolbize, A. (2008). Generational differences in the workplace. Research and training center on community living, $5(2), 1-21$.

Vakola, M., Tsaousis, I. \& Nikolaou, I. 2003. The role of emotional intelligence and personality variables on attitudes toward organizational change. Journal of Managerial Psychology, 19, 88-110.

Van der Voet, J., Kuipers, B. S., \& Groeneveld, S. (2016). Implementing Change in Public Organisations: The relationship between leadership and affective commitment to change in a public sector context. Public Management Review, 18(6), 842-865.

Wainwright, D. (2008). The training manager as a change agent. Training Journal, 1(2), 56-59.

Walker, H. J., Armenakis, A. A., \& Bernerth, J. B. (2007). Factors influencing organisational change efforts: An integrative investigation of change content, context, process and individual differences. Journal of Organisational Change Management, 20(6), 761-773.

Wikhamn, W., \& Hall, A. T. (2012). Social exchange in a Swedish work environment. International Journal of Business and Social Science, 3(23).

\section{Copyrights}

Copyright for this article is retained by the author(s), with first publication rights granted to the journal.

This is an open-access article distributed under the terms and conditions of the Creative Commons Attribution license (http://creativecommons.org/licenses/by/4.0/). 